Thomas Jefferson Among the Arts

An Essay in Early American Esthetics. By Eleanor Davidson Berman. Pp. xviii $+305+20$ plates. (New York: Philosophical Library, Inc., 1947.) 3.75 dollars.

T view of the distinguished position occupied by $I$ the United States to-day, one is perhaps apt to forget what strife and labour went into the development of the young republic in the period of its third president. Those were times when 'art' was too expensive, yet in all its forms, so much to be desired. Thus we find Jefferson the revolutionary, workman, writer, thinker, toiling ever and anon to establish culture, both abstract and material, in his youthful America. To him there was no difference between 'pure' and 'applied' (whether art or science) ; all was for the benefit of mankind, and the pursuit of the good. Naturally, this led to some strong likes and dislikes, short shrift for Plato and Samuel Johnson, to mention but two.

Love of contrast is characteristic ; formal Palladian architecture, surrounded by 'serpentine' gardens, as if to say "Oh Western Wind, blow soft and kind" upon the exceedingly solid and uncompromising stone buildings he admired and advocated. The author of the Declaration of Independence is entitled to such light and shade in his dealings with contem. porary events.

The book itself is a careful document on the whole, somewhat disfigured by a fantastic misprint ("Nogarth" for Hogarth) on Plate 10, but pleasant to read and valuable for its references. It depicts Jefferson the man, very much a son of the Enlightenment, the master-craftsman of his age. F. I. G. RAwLINS

\section{Magnetic Materials}

By Dr. F. Brailsford. (Methuen's Monographs on Physical Subjects.) Pp. ix+156. (London: Methuen and Co., Ltd., 1948.) $6 s$. net.

$\Gamma$ HE appearance of this excellent monograph is opportune. During the past decade there have been immense advances in the quality of magnetic materials, both for cores of special transformers, electro-magnets, and particularly for permanent magnets, leading to greatly improved instruments, methods of measurement, and components generally. In one field alone, that of recording sounds on wire or powder, the whole process of magnetization had to be re-investigated, with a resulting new idea in the selection of material, leading to the sudden improve. ments which are about to be made commercial.

The author gives the clues to these reconsiderations, by relating the observed phenomena to defects in the shells of electrons and the rigidity or otherwise of the erystal lattice. Theory has indicated the lines of advance, and, in the laboratory, there are already 'better' (that is, better for special purposes) materials which are impracticable only by reason of cost.

The main purpose is, however, to give a complete story of the theory behind the materials, and this is offered with the utmost clarity. L. E. C. H.

\section{Fahrten in Island}

Von Rudolf Jonas. Pp. $198+83$ plates.

L. W. Siedel und Sohn, 1948.) 3.50 dollars.

$\mathrm{TN}^{\mathrm{N}} 1935$ a party of Austrian scientists under Dr. R. Jonas and Prof. F. Nusser made a crossing of Vatnajökull, Iceland. The personnel was organised by the Austrian Students' Travel Association. The participation of the National Union of Students in
England was proposed but could not be arranged in time. Some glaciological research was completed and part of the northern margin of the ice was mapped. This book is concerned mainly with that expedition and contains some good accounts of Icelandic scenery. The nunatak known as Mount Paul was rediscovered and fixed, and the crater of Sviagigur was explored. The numerous illustrations are excellent and the maps are adequate.

\section{Cosmic Rays and Nuclear Physics}

By Prof. L. Jánossy. (Frontiers of Science Series.) Pp. xiv + 186. (London: Pilot Press, Ltd., 1948.) $9 s .6 d$. net.

THIS is a more popular version of the book on cosmic rays by the same author which was reviewed in Nature of May 22, p. 785, 1948. The subjects treated, and their ordering, are much the same as in that book, though less detail is given. Theory is, in the main, omitted ; but the most important formulæ are quoted, and a valiant effort is made to explain how they are derived. The book, like the earlier one, aims at comprehensiveness; but is not too well arranged.

The Frontiers of Science Series, of which the book forms part, aims at serving the non-specialist public who have outgrown the 'told to the children' approach. But this book can appeal only to a restricted public; for example, it introduces without explanation technical terms like azimuth, pentode, radius of curvature, electron volt, rest mass and energy, relativistic velocity, etc., and the fact that relativistic ideas are in principle explained later would scarcely compensate for the confusion which their first mention would evoke. The book could be read with profit by a man who has taken a science degree with physics as at least a subsidiary part, or by a brilliant schoolboy, and can be recommended to people like these. But it is not a popular book in anything like the usually accepted sense; it is a beginner's research manual, characterized by the researcher's inclusion of much detail, many references, and minor qualifications of general statements. It can be warmly recommended to people of the right sort; but one cannot agree that it achieves the avowed aim of the Series in that it "requires no previous specialized knowledge".

\section{T. G. Cowling}

\section{Adventures with a Naturalist}

By Roy Bedichek. Pp. 258. (London: Victor Gollancz, Ltd., 1948.) 12s. 6d. net.

THE scene of this book is in Texas, and its theme is the effect of the white man on animal and plant life. The author begins: "I have been looking over a two-hundred-acre plot of fenced land and trying to compare the life it now supports with that which it had been supporting for thousands of years when the first white man occupied it a hundred years ago". Although Mr. Roy Bedichek entitles his work, "Adventures with a Naturalist", although the title is excellent and he takes us on many delightful adventures observing a variety of birds, mammals and plants, we ever come back to the distressing effect of the white man, his agriculture and other activities, on the indigenous fauna and flora, an all too sad effect not limited to the American continent, but assoeiated with him the world over. This is an interesting and pleasant book, despite its preoccupation with a mournful theme, and covers a wide field of Nature and country life.

Frances Pitt 